\title{
Rapid communication Organic matter and heavy metals in grey-water sludge
}

\author{
E Eriksson*, S Srigirisetty and AM Eilersen \\ Department of Environmental Engineering, Technical University of Denmark, DK-2800 Kgs. Lyngby, Denmark
}

\begin{abstract}
Grey-water intended for non-potable reuse is being intensively studied, but little attention has been given to the associated solid fraction, the grey-water sludge. In this study grey-water sludge originating from bathroom grey-water has been screened with respect to organic matter; particles; short-chain fatty alcohols and acids; selected metals and basic parameters as well as characterization of the organic matter content by oxygen utilization rate (OUR). The grey-water sludge contains metal loads comparable to Danish sewage sludge, and it exceeds the Danish quality criteria for spreading on agricultural land for cadmium and nickel. If dewatered and managed as soil it would be classified as 'Class 3; polluted soil' with respect to cadmium, copper and nickel. The OUR results indicate that the grey-water biological sludge contains an equivalent amount of readily degradable organic matter compared to municipal activated sludge. But it contains $35 \%$ more readily, and $90 \%$ more slowly, hydrolysable organic matter than municipal sludge.
\end{abstract}

Keywords: cadmium, copper, grey wastewater, lead, nickel, suspended solids

\section{Introduction}

Grey-water, namely, domestic wastewater without input from toilets and bidets, is an alternative water source for non-potable applications, such as toilet flushing and ornamental irrigation, after appropriate treatment. The development of grey-water use is driven by environmental concerns such as mitigation of resource depletion, adaptation to climate change and the desire for a sustainable lifestyle. As such the pool of knowledge on grey-water composition and flow has been expanded during the first decade of the $21^{\text {st }}$ century, especially with respect to xenobiotic organic compounds (XOCs). However, little attention has been given to its corresponding solid compartment, the grey-water sludge, which consists of semi-solid material which has settled and precipitated in grey-water treatment systems. In an urban context, many treatment and reuse systems discharge into the combined sewer system and are subsequently subjected to treatment in municipal wastewater treatment plants (WWTP), but in rural areas it may be disposed of on land without any preceding sludge treatment. The information regarding the composition of grey-water sludge available in the literature is sparse if not non-existent. Thus, it is important to characterise the grey-water sludge with respect to organic matter, particles, nutrients, heavy metals, XOCs and microorganisms, in order to be able to determine the best available practice for sludge management in both urban and rural contexts. The aim of this research was to screen the composition of grey-water sludge derived from grey-water originating in bathrooms (hand basins and showers), with respect to particulate and organic matter, nutrients and selected metals (cadmium $(\mathrm{Cd})$, nickel $(\mathrm{Ni})$ and lead $(\mathrm{Pb})$ as requested in the European Water Framework Directive (WFD, 2000/60/EC) (European Commission, 2000) as well as copper $(\mathrm{Cu})$ ).

* To whom all correspondence should be addressed.

疋 (+45) 452516 00; fax: (+45) 459328 50; e-mail: eve@env.dtu.dk

Received 30 October2009; accepted in revised form 8 January 2010.

\section{Experimental}

\section{Sampling site and sampling}

Samples were collected in a grey-water treatment plant located in Copenhagen (Denmark), which utilises a treatment train comprising a collection tank, a 3-stage rotating biological contactor (RBC), a secondary settling tank, a sand filter, and a UV-disinfection step before the treated water is collected in a service water tank prior to application for toilet flushing. The average daily demand is 5 to $6 \mathrm{~m}^{3}$ and feed water of potable water is added to the service water tank covering $8 \%$ of the total flow. The hydraulic retention time (HRT) of the whole plant is 29 to 33 hours (Eriksson et al., 2009). Three grab samples of sludge fractions and effluent grey-water were taken, as well as 12 grab samples of the influent grey-water. Sampling locations are shown in Table 1. Acid-washed equipment was used.

\begin{tabular}{|l|c|}
\hline \multicolumn{2}{|c|}{$\begin{array}{c}\text { Table 1 } \\
\text { Sampling locations and sample characteristics } \\
\text { descriptions }\end{array}$} \\
\hline Description & Abbreviation \\
\hline Raw grey-water (whole influent) & A0 \\
\hline Primary settled sludge & A1 \\
\hline Dewatered primary settled sludge & SRS \\
\hline Biological sludge & B1 \\
\hline Secondary settled sludge & C3 \\
\hline Sludge deposition in the service water tank & ET \\
\hline Effluent from the service water tank (whole effluent) & A7 \\
\hline
\end{tabular}

\section{Analyses}

Dissolved oxygen (DO) and $\mathrm{pH}$ were analysed by calibrated field-kit equipment (WTW Oxi 340i/SET and WTW pH330i $\mathrm{pH}-$ meter). Organic matter, chemical oxygen demand $\left(\mathrm{COD}_{\mathrm{C}}\right)$ and biological oxygen demand $\left(\mathrm{BOD}_{5}\right)$ were analysed according to standard methods (ISO 6060:1989 and ISO 5815-1:2003). 
Particulate matter, total solids (TS), total suspended solids (TSS) and volatile suspended solids (VSS) were analysed according to Eaton et al. (2005). Nutrients; nitrate and nitrite $\left(\mathrm{NO}_{3}-\mathrm{N}+\mathrm{NO}_{2}-\mathrm{N}\right)$ and ammonia $\left(\mathrm{NH}_{4}-\mathrm{N}\right)$ were analysed according to standard methods (ISO 13395:1996 and ISO 11732:2005) whereas ortho-phosphate was analysed spectrophotometrically after a filtration at $<0.45 \mathrm{~mm}$ (Eaton et al., 2005). Short-chain fatty alcohols and acids (ethanol, 1-propanol, 1-butanol, isoamylalcohol, acetate, propionate, iso-butyrate, butyrate, isovalerate, valerate and hexanoic acid) were analysed according to Pind et al. (2003). Samples intended for metal analysis were filtered through a $10 \mathrm{~mm}$ filter (Munktell 00R) and acidified (DS 259:2003) before analysis by Inductively Coupled Plasma (Varian Vista-MPX CCD Simultaneous ICP-OES). The analyses were conducted according to internal quality control procedures. An oxygen utilisation rate (OUR) experiment was conducted according to Ledin et al. (2006). For comparison a sludge sample from an activated sludge tank at Lundtofte Municipal WWTP were also tested as a reference simultaneous to the grey-water biological sludge (B1) sample. Lundtofte WWTP receives both domestic and industrial wastewater and stormwater, has a capacity of 114000 person equivalents (PE), and applies tertiary treatment of the wastewater (physical, chemical and biological treatment) (Mølleåværket, 2008).

\section{Results and discussion}

The results presented here reflect a limited screening of sludge samples in different tanks in the treatment plant. As no data on grey-water sludge characteristics could be found in the literature during an international review (covering 1969 to 2009; for grey-water see Eriksson et al., 2002), the result is compared with municipal sewage sludge when relevant. Hence, in order to evaluate the efficacy of grey-water treatment systems, perform mass balances and govern grey-water reuse it is of vital importance to further investigate grey-water sludge, also addressing sludge retention time (SRT) and biomass composition.

\section{Basic parameters and organic matter}

The influent grey-water and the initial 3 sludge fractions are low on oxygen, but after treatment in the RBC, which is open to the ambient air, the DO concentrations are sufficiently high to avoid any unpleasant odours (Table 2). The dewatered primary settled sludge (SRS) is anaerobic $(<1 \mathrm{mg} \mathrm{DO} / \ell)$. The $\mathrm{pH}$ shows a similar pattern to DO and the lowest $\mathrm{pH}(7.0-7.1)$ was noted for SRS. This can be explained by degradation of organic matter yielding short-chain fatty acids.

The highest influent COD value $(850 \mathrm{mg} / \ell)$ is greater, but in the same order of magnitude as found for bathroom grey-water in literature (Eriksson et al., 2002). BOD in the influent stream agrees with data reported in the literature. As the data set is limited, no detailed analysis of the treatment efficiency can be made, but for COD and BOD it seems as if the treatment efficiency from A0 to A7 is high, in the range of 83 to $99 \%$ and $>94$ to $>99 \%$, respectively. The COD show a substantial variation for B1 and ET, which could be a consequence of cleaning the tanks with tap water before the final sampling (Sørensen, 2008). The SRS COD content also differed between samplings but in this case the water content is highly dependent on the dewatering cycle.

In the 12 influent samples only ethanol, out of all the shortchain fatty alcohols, was found to be present above the detection limit (DL), namely 24 to $59 \mathrm{mg} / \ell$. As ethanol is a common solvent used in household chemicals and personal care products (Eriksson et al., 2003) it is also likely to be found in the influent water. Ethanol was detected ( 24 to $141 \mu \mathrm{g} / \ell$ ) in B1. Acetate was found to be present in concentrations between 43 and $48 \mu \mathrm{g} / \ell$ in the SRS, thus yielding 7.8 to $18 \mathrm{mg}$ acetate/ $\mathrm{kg}$ dry weight (dw). In municipal sewage sludge the content of acetate varies between 40 and $400 \mathrm{mg} / \mathrm{kg}$ dw (Ucisik and Henze, 2008). All of the short-chain fatty acids were at levels that did not exceed the DL in all of the other samples. As many substances have been proven to be present in both grey-water and municipal wastewater, and as it is a well-known fact that municipal sewage sludge often cannot be disposed of on agricultural land due to the presence of many XOCs, it is also likely that grey-water sludge will contain an important part of the XOCs which were removed from the water phase during treatment, depending on the inherent properties of the concerned XOC.

\section{Particulate matter and nutrients}

TSS, VSS, and nutrients in the influent do not differ from what has been published in the literature for 'bathroom' grey-water (Eriksson et al., 2002). In Table 3 the TSS results confirm what could be seen by visual inspection during sampling; dewatered (SRS) and biological (B1) sludge contain more solid matter than the other sludge fractions. The same variability noted for organic matter can be seen here. TSS and VSS were also analysed in the same samples, and are thus directly comparable. The ratio between VSS and TSS in the influent ranged from 29 to $75 \%$ with an average of $49 \%$, but in the sludge phases the ratio is generally a little higher: 46 to $66 \%$ in A1, 60 to $63 \%$ in SRS, 70 to $73 \%$ in B1, 72 to $82 \%$ in C3 and 57 to $64 \%$ in ET.

The decrease in ammonium and the increase in nitratenitrite seen along the treatment train confirm what has been suggested before for the same treatment plant (Eriksson et al., 2009); namely, that nitrification occurs. Nitrification has previous been identified in a membrane bio-reactor (MBR) treating

\begin{tabular}{|c|c|c|c|c|}
\hline \multicolumn{5}{|c|}{$\begin{array}{c}\text { Table } 2 \\
\begin{array}{c}\text { Basic parameters in grey-water sludge as well as grey-water influent } \\
\text { and effluent (in } \mathrm{mg} / \mathrm{l} \text { ) }\end{array}\end{array}$} \\
\hline & $\mathrm{DO}(n=2)$ & $\mathrm{pH}(n=2)$ & $\operatorname{COD}_{c_{r}}(n=2)$ & $\mathrm{BOD}_{5}(n=2)$ \\
\hline A0 & $2.5-4.5(n=12)$ & $7.7-8.1(n=12)$ & $76-850(n=12)$ & $18-68(n=4)$ \\
\hline A1 & $1.4-2.5$ & $7.1-7.8$ & $330-580$ & 160 \\
\hline SRS & $<1$ & $7.0-7.1$ & $380-2900$ & 170 \\
\hline $\mathrm{B} 1$ & $<1-1.9$ & $7.4-7.9$ & $200-9800$ & $>1240$ \\
\hline $\mathrm{C} 3$ & $7.6-7.8$ & $8.3-8.4$ & $60-64$ & $<3$ \\
\hline ET & $9.3-9.5$ & $7.8-8.2$ & $8.8-5900$ & $<3$ \\
\hline A7 & $9.3-9.5$ & $8.2-8.3$ & $12-13$ & $<3$ \\
\hline
\end{tabular}

$n=$ number of samples 


\begin{tabular}{|c|c|c|c|c|c|c|}
\hline \multicolumn{7}{|c|}{$\begin{array}{r}\text { Table } 3 \\
\text { Particulate matter and nutrients in grey-wa }\end{array}$} \\
\hline & $\begin{array}{c}\text { TS } \\
(n=2)\end{array}$ & $\begin{array}{c}\text { TSS } \\
(n=3)\end{array}$ & $\begin{array}{l}\text { VSS } \\
(n=3)\end{array}$ & $\begin{array}{l}\mathrm{NO}_{3}-\mathrm{N}+\mathrm{NO}_{2}-\mathrm{N} \\
(n=2)\end{array}$ & $\begin{array}{l}\mathrm{NH}_{4}-\mathrm{N} \\
(n=2)\end{array}$ & $\begin{array}{l}\text { Ortho-PO }{ }_{4}-\mathrm{P} \\
(n=2)\end{array}$ \\
\hline A0 & & $\begin{array}{l}51-135 \\
(n=12)\end{array}$ & $\begin{array}{l}28-56 \\
(n=12)\end{array}$ & $\begin{array}{l}0.01-0.68(n= \\
12)\end{array}$ & $\begin{array}{c}0.36-4.4 \\
(n=12)\end{array}$ & $\begin{array}{c}0.02-2.2 \\
(n=12)\end{array}$ \\
\hline $\mathrm{A} 1$ & 20000 & $110-790$ & $51-560$ & $0.05-0.17$ & $2.1-2.4$ & $0.27-0.41$ \\
\hline SRS & $\begin{array}{c}2000-6100 \\
(n=3)\end{array}$ & $560-14600$ & $400-8700$ & $0.02-0.03$ & $13-17$ & $1.9-2.3$ \\
\hline B1 & $1300-9200$ & $230-19100$ & $160-13500$ & $0.03-0.04$ & $1.7-1.8$ & $0.18-0.19$ \\
\hline $\mathrm{C} 3$ & & $65-72$ & $47-59$ & $4.3-4.6$ & $0.10-0.32$ & $0.61-0.63$ \\
\hline ET & 720 & $32-43$ & $15-26$ & $1.8-2.3$ & $0.06-0.09$ & $0.23-0.24$ \\
\hline A7 & & $67-390$ & $38-248$ & $1.8-2.0$ & $0.07-0.13$ & $0.25-0.28$ \\
\hline
\end{tabular}

grey-water (LesJean and Gnirss, 2006). As expected, the ammonium and phosphate concentrations are higher in the SRS than in $\mathrm{A} 1$ due to the dewatering.

LesJean and Gnirss (2006) found that in a membrane bioreactor the nitrogen mass captured in the grey-water sludge derived from bathroom and kitchen grey-water would be around $36 \mathrm{~g} / \mathrm{d}$ for a load of $50 \mathrm{PE}$, while using an ammonium concentration of $5.7 \mathrm{mg} \mathrm{N} / \ell$, which is within the range found here. The nutrient concentrations in municipal sludge show a wide range, and nitrogen and phosphorus can be assimilated into biomass in the ranges of 80 to $120 \mathrm{mg} \mathrm{N} / \mathrm{g}$ VSS and 10 to $25 \mathrm{mg}$ P/g VSS (Henze et al., 2002). For the biological greywater sludge (B1), the corresponding values were 0.22 to $11 \mathrm{mg}$ $\mathrm{N} / \mathrm{g}$ VSS (nitrite, nitrate and ammonium) and $<0.1$ to $1.1 \mathrm{mg}$ $\mathrm{P} / \mathrm{g}$ VSS (phosphate). The measured nitrogen fraction does not represent the total nitrogen as the organic nitrogen is missing; nonetheless the sludge in B1 contained less nitrogen per gram of VSS than that of municipal sewage sludge. The same can be said for phosphorus.

\section{Selected metals in grey-water and grey-water sludge}

WFD metals and other metals have not been studied in great detail in grey-water (Eriksson et al., 2002) but the concentrations found in the influent and effluent grey-waters (Table 4) agree with results obtained in Sweden (Palmquist and Hanaeus, 2005), with the exception of 1 high Cd value $(9.0 \mu \mathrm{g} / \ell)$ in A7.

Here, of course, the background concentrations in hot and cold tap water (from piping, etc.), and not only the household activities, will have a profound effect on the metal content.

The results for the sludge samples were normalised to dry weight (Table 5). The ET had not been cleaned since the installation of the plant in 2001, according to the plant manager (Sørensen, 2008); hence, this could be a plausible explanation for the comparably high metal concentrations found in the ET sludge (Table 5).

The sludge metal concentrations for the WWTP to which the grey-water treatment plant is connected (Lynettefællesskabet, 2008) were calculated to be $1.2 \mathrm{mg} / \mathrm{kg}$ $\mathrm{dw}$ for $\mathrm{Cd}, 300$ for $\mathrm{Cu}, 22$ for $\mathrm{Ni}$ and 83 for $\mathrm{Pb}$. These figures fit well with the concentrations in the grey-water sludge and it cannot be confirmed that there is a significant difference based on this study. The limit values for applying (municipal) sludge on agricultural land in Denmark are $0.8 \mathrm{mg} / \mathrm{kg} \mathrm{dw}$ for Cd, 1000 for $\mathrm{Cu}, 30$ for $\mathrm{Ni}$ and 120 for $\mathrm{Pb}$ (The Danish Ministry of the Environment, 2006). The grey-water sludge complies with the limits for $\mathrm{Cu}$ and $\mathrm{Pb}$ but exceeds it for $\mathrm{Cd}$ and $\mathrm{Ni}$, which means that this sludge could not be spread on agricultural land.

\begin{tabular}{|l|c|c|c|c|}
\hline \multicolumn{5}{|c|}{ Table $\mathbf{4}$} \\
\multicolumn{5}{|c|}{ Metals in grey-water influent and effluents in $\boldsymbol{\mu g} / \boldsymbol{\ell}(\boldsymbol{n}=\mathbf{3})$} \\
\hline & $\mathbf{C d}$ & $\mathbf{C u}$ & $\mathbf{N i}$ & $\mathbf{P b}$ \\
\hline A0 & 0.1 & $8.7-11$ & $7.0-39$ & $2.5-3.1$ \\
\hline A7 & $<0.1-9.0$ & $8.5-25$ & $5.5-9.7$ & $1.8-3.2$ \\
\hline
\end{tabular}

\begin{tabular}{|l|c|c|c|c|}
\hline \multicolumn{5}{|c|}{ Table 5 } \\
Metals in grey-water sludge $(\boldsymbol{n}=\mathbf{3}$, in $\mathbf{~ m g / k g ~ d w})$ \\
\hline & $\mathbf{C d}$ & $\mathbf{C u}$ & $\mathbf{N i}$ & $\mathbf{P b}$ \\
\hline A1 & 0.08 & 34 & 5.5 & 2.8 \\
\hline SRS & $0.67-1.2$ & $330-510$ & $24-35$ & $34-45$ \\
\hline B1 & 1.1 & $470-510$ & $22-69$ & $34-47$ \\
\hline ET & 1.5 & 640 & 100 & 77 \\
\hline
\end{tabular}

If the grey-water sludge were to be dewatered and handled outside the sewer system, but not used in agriculture, it would be regarded as contaminated soil and be graded according to the local soil classes (Counties of North Zealand, 2004). In such a case $\mathrm{Cd}, \mathrm{Cu}$ and $\mathrm{Ni}$ would be 'Class 3; polluted soil' requiring treatment or disposal, whereas $\mathrm{Pb}$ would be Class 2; lightly polluted soil' which can be used for, e.g., construction, after an environmental permit has been obtained. As the samples were filtered before analysis it cannot be excluded that the total metal content would be higher if the larger $(>10 \mu \mathrm{m})$ particulate fraction were also included.

\section{OUR}

Table 6 exhibits the degradation of organic matter, expressed as DO, in grey-water sludge and activated sludge from Lundtofte WWTP over $50 \mathrm{~h}$. The OUR results indicate that the greywater biological sludge and municipal activated sludge contain equivalent amounts of easydegradable organic matter at $8 \mathrm{mg} \mathrm{COD} / \mathrm{g}$ VSS. However, the grey-water sludge contained $35 \%$ more easily- and $90 \%$ more slowly-hydrolysable organic matter than municipal sludge, assuming a yield factor of 0.5 (Smidt, 2008) (Table 6).

The total amount of COD measured was $91 \mathrm{mg} / \mathrm{g}$ VSS for the grey-water sludge and $57 \mathrm{mg} / \mathrm{g}$ VSS for the municipal sludge. The final fractionation of COD in the grey-water sludge is therefore $9 \%$ readily degradable, $28 \%$ easy hydrolysable and $63 \%$ slowly hydrolysable organic matter, whereas the fractions are distributed as $15 \%$ readily degradable, $33 \%$ easyhydrolysable and 52\% slowly hydrolysable organic matter for municipal activated sludge Fig. 1). Further research is needed but Henkel et al. (2009) have observed that the degradation processes in grey-water laboratory and pilot-scale systems improve with 


\begin{tabular}{|l|c|c|c|c|c|c|}
\hline \multicolumn{7}{|c|}{ Table 6} \\
COD fractionation in grey-water sludge and activated sludge (in mg DO/g VSS-h) \\
\hline
\end{tabular}
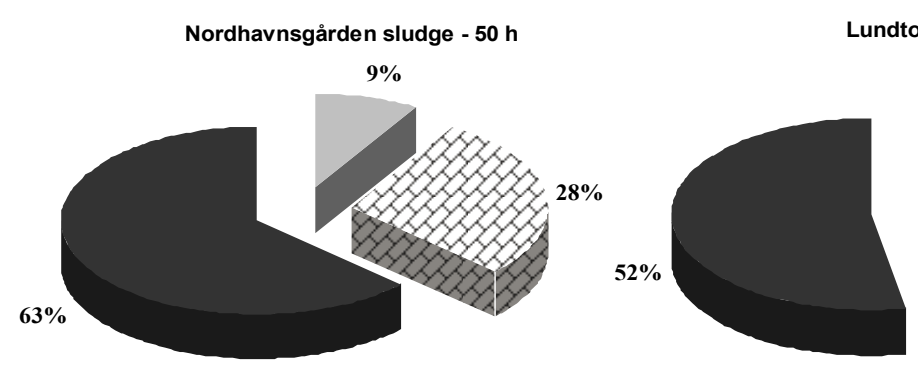

Lundtofte sludge $-50 \mathrm{~h}$

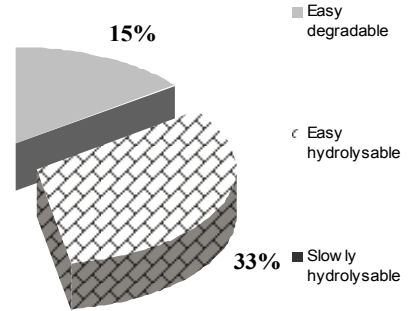

Figure 1

OUR in for grey-water biological sludge for $50 \mathrm{~h}$ (left) and Lundtofte municipal activated sludge (right) increasing SRT, which advocates for good management of the grey-water sludge.

\section{Conclusions}

The grey-water sludge in this study was found to contain the same amount of metals (in $\mathrm{mg} / \mathrm{kg}$ dry weight) as the municipal sewage sludge produced by the wastewater treatment plant to which the grey-water treatment plant is connected. The oxygen utilisation rate test indicated that the grey-water biological sludge has a higher content of organic matter, but the same content of readily degradable organic matter, when compared to municipal activated sludge. In order to determine the best way to manage grey-water sludge in a sustainable manner it is important that more data on the composition and production rate become available.

\section{References}

COUNTIES OF NORTH ZEALAND (2004) Vejledning i Håndtering af forurenet jord på Sjælland af Amterne på Sjælland og Lolland/ Falster samt Frederiksberg og Københavns kommuner fra juli 2001 og revideret i maj 2004. URL: h tp://www3.kk.dk/Erhverv/Milioe IordVandOgOlie/Jord/ /media/03CF82BDC9DD4ECB9991F73349 0527D8.ashx (Accessed 21 May 2009).

EATON A, CLESCERI LS, GREENBERG AE and RICE EW (Eds.) (2005) Standard Methods for the Examination of Water \& Wastewater. American Public Health Association Publications, $21^{\text {st }}$ edn., November 2005.

ERIKSSON E, ANDERSEN HR, MADSEN TS and LEDIN A (2009) Greywater pollution variability and loadings. Ecol. Eng. $\mathbf{3 5}$ 661-669.

ERIKSSON E, AUFFARTH K, EILERSEN A-M, HENZE M and LEDIN A (2003) Household chemicals and personal care products as sources for xenobiotic organic compounds in grey wastewater. Water SA 29 135-146.

ERIKSSON E, AUFFARTH K, HENZE M AND LEDIN A (2002) Characteristics of grey wastewater. Urban Water 4 85-104.

EUROPEAN COMMISSION (2000) Directive 2000/60/EC of the European Parliament and of the Council of 23 October 2000 establishing a framework for Community action in the field of water policy. URL: h ttp://eur-lex.europa.eu/LexUriServ/LexUriServ. do? uri=CELEX:32000L0060:EN:NOT (Accessed 10 June 2009).
HENKEL J, CORNEL P and WAGNER M (2009) Free Water Content and Sludge Retention Time: Impact on Oxygen Transfer in Activated Sludge. Environ. Sci. Technol. 43 8561-8565.

HENZE M, HARREMOËS P, LA COUR JANSEN J, and ARVIN E (2002) Wastewater Treatment: Biological and Chemical Processes $\left(3^{\text {rd }}\right.$ edn.) Springer-Verlag Berlin, Heidelberg, New York.

LEDIN A, AUFFARTH K, ERIKSSON E, SMITH M, EILERSEN AM, MIKKELSEN PS, DALSGAARD A and HENZE M (2006) Udvikling af metode til karakterisering af gråt spildevand. Miljøstyrelsen, København. Økologisk byfornyelse og spildevandsrensning, 58 2006. URL: h ttp://www2.mst.dk/Udgiv/publikationer/2006/87-7052-116-6/pdf/87-7052-117-4.pdf)(Accessed 8 August 2009)

LESJEAN B and GNIRSS R (2006) Grey water treatment with a membrane bioreactor operated at low SRT and low HRT. Desalination 199 432-434.

LYNETTEFÆLLESSKABET I/S (2008) Environmental data 2007 for WWTP Lynetten and Damhusåen.URL: http://www.lyn-is.dk/ Lynettef\%C3\%A6llesskabet/Publikationer.aspx)(Accessed 21 May 2009)

MØLLEÅVÆRKET (2008) Renseanlæg Lundtofte (Wastewater treatment plant Lundtofte). URL: hltp://www.renslundtofte.dk/ (Accessed 10 December 2008).

PALMQUIST H and HANAEUS J (2005) Hazardous substances in separately collected grey- and blackwater from ordinary Swedish households. Sci. Total Environ. 348 151-163.

PIND PF, ANGELIDAKI I and AHRING BK (2003) Dynamics of the Anaerobic Process: Effects of Volatile Fatty Acids. Biotechnol. Bioeng. 82 791-801.

SMIDT M (2008) Investigation of the VFA potential in aquaculture sludge using anaerobic hydrolysis and characterization of the organic fraction by OUR. Masters thesis, Department of Environmental Engineering, Technical University of Denmark, April 2008.

SØRENSEN J (2008) Personal communication, December 2008, with the Nordhavnsgården plant manager, employed by FSBbolig, Denmark.

THE DANISH MINSTRY OF THE ENVIRONMENT (2006) Statutory order on use of waste for agricultural land (Slambekendtgørelsen) BEK nr 1650 from 13 December 2006. URL: htetp://www. etsinformation.dk/ (Accessed 31 August 2007).

UCISIK AS and HENZE M (2008) Biological hydrolysis and acidification of sludge under anaerobic conditions: The effect of sludge type and origin on the production and composition of volatile fatty acids. Water Res. 42 (14) 3729-3738. 